\title{
A new species of Taylorius (Bryozoa: Escharinidae) from the east coast of South Africa
}

\author{
Jody-Carynn Oliver \\ Natural History Collections Department, Iziko Museums of South Africa, P.O. Box 61, Cape Town, 8000 South Africa \\ E-mail: joliver@iziko.org.za \\ \& \\ Wayne K. Florence* \\ Natural History Collections Department, Iziko Museums of South Africa, P.O. Box 61, Cape Town, 8000 South Africa \\ E-mail:wflorence@iziko.org.za \\ (with 1 figure and 1 table)
}

Received 26 May 2015. Accepted 30 November 2015

\begin{abstract}
A new species of Escharinidae, Taylorius nyembezi sp. nov., is described and illustrated from material collected by the R.V. Meiring Naudé cruises at $90 \mathrm{~m}$ depth off the east coast of South Africa in 1979 and lodged in the collections of the Iziko Museums of South Africa, Cape Town and The Natural History Museum, London. The specimens were previously reported as conspecific with recent and fossil specimens from New Zealand and misidentified as Escharina waiparaensis (Brown, 1952) by Hayward \& Cook (1983). Subsequently Gordon (2014) clarified the taxonomic status of the unique species that constitutes Escharina waiparaensis. In this paper we erect Taylorius nyembezi sp. nov., for the South African specimens based on its unique anter and sinus shape, metrics of its zooids and orifices, and the large size and position of the spine bases.
\end{abstract}

Key words: Bryozoa, Escharinidae, Taylorius, new species, historical specimens, South Africa.

\section{CONTENTS}

\begin{tabular}{|c|}
\hline 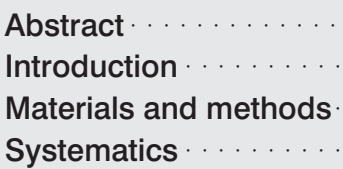 \\
\hline
\end{tabular}

INTRODUCTION

The genus Escharina Milne Edwards, 1836, is one of the most diverse and taxonomically difficult genera of the family Escharinidae (Tilbrook 2006). This genus has been studied and clarified by a number of taxonomists, which include: Brown (1952), Buge (1957), David \& Pouyet (1978) and Berning et. al. (2008). Several authors have erected new genera that were previously included in Escharina Milne Edwards, 1836; Herentia Gray, 1848; Therenia David \& Pouyet, 1978; Phaeostachys Hayward, 1979; Bryopesanser Tilbrook, 2006 and Taylorius Gordon, 2014. Given the clearly weak characterization of Escharina Milne Edwards, 1836 further taxonomic research on this taxon is likely to reveal a number of cryptic generic taxa (Gordon 2014).

The most recent genus to be erected that was previously included in Escharina is Taylorius based on the nature of its pseudoporous frontal shield, regularly paired small heterozooids and setiform avicularian mandibles, fully cleithral ovicells and lack of a peristome. Gordon (2014) proposed new combinations for two fossil species, viz. Taylorius masoni (Brown, 1952) previously Escharina masoni and Taylorius waiparaensis (Brown, 1952) previously Escharina waiparaensis, and erected Taylorius cylindratus (Gordon, 2014) previously Escharina waiparaensis, Taylorius arcuatus (Gordon, 2014) previously Escharina waiparaensis and Taylorius spinosus (Gordon, 2014) as a new species from New Zealand. The confused synonomy of Escharina waiparaensis was, in particular, dealt with comprehensively and clarified by Gordon (2014). Furthermore, he noted that specimens from South Africa and Australia require further taxonomic examination as his preliminary opinion suggested that these warrant placement in the genus Taylorius, with the African specimens representing a potentially new species.

This study aims to give an account of a new species of Taylorius, Taylorius nyembezi sp. nov., from specimens collected by the R.V. Meiring Naudé; previously reported from South Africa as Escharina waiparaensis by Hayward \& Cook (1983) and alluded to in Gordon (2014).

\section{MATERIALS AND METHODS}

The taxon described here was collected during the R.V. Meiring Naudé cruise, that was performed by the South African Museum's Department of Marine Biology in 1979. The biological material collected was preserved in a mixture of sea water and formalin and later transferred to $70 \%$ ethanol. 
The material was sub-sampled and later bleached in a weak $5 \% \mathrm{NaOCl}$ (domestic bleach) solution in order to remove all debris and organic material. The sub-sampled specimen was left to dry in a ventilated chamber for 24 hours and then studied by scanning electron microscopy using a JEOL-5200 SEM. Measurements of the morphological features of the relevant specimen were made using an optical eyepiece micrometer; taken mostly in the zone of astogenetic repetition and given in the text as the observed range and mean (the latter in brackets). Measurements (in $\mu \mathrm{m}$ ) are given in the text for the following characters: autozooid length (ZL) and width $(\mathrm{ZW})$, orifice length $(\mathrm{OL})$ and width $(\mathrm{OW})$, and anter length (AntL). Mean sinus to OL ratio (SOLR), which is a diagnostic feature for the taxon reported here,was calculated for selected Taylorius species using the following equation:

$$
\text { SOLR }=\frac{(\mathrm{OL})-(\text { AntL })}{(\mathrm{OL})}
$$

Holotype and paratype specimens were assigned for historical specimens lodged in the collections of the Natural History Collections Department, Iziko Museums of South Africa, Cape Town, and The Natural History Museum, London, respectively. The taxonomic opinion and classification expressed below is based on the most recent opinion of Gordon (2014).

\section{SYSTEMATICS}

\section{Class GYMNOLAEMATA Allman 1856 Order CHEILOSTOMATA Busk 1852 \\ Suborder NEOCHEILOSTOMINA d'Hondt 1985 Superfamily SCHIZOPORELLOIDEA Jullien 1882 Family ESCHARINIDAE Tilbrook 2006}

\section{Genus Taylorius Gordon, 2014}

Type species: Taylorius cylindratus Gordon, 2014

\section{Taylorius nyembezi sp. nov.}

Fig. $1 \mathrm{~A}-\mathrm{F}$

\section{Etymology}

nyembezi (isiXhosa) - tear; named for the characteristically teardrop-shaped sinus.

\section{Material examined}

Holotype: SAMC-A026610, SM239 - Eastern Cape, South Africa $\left(32^{\circ} 14.8^{\prime} \mathrm{S} 29^{\circ} 00.8^{\prime} \mathrm{E}\right)$, depth $90 \mathrm{~m}$, collected by the R.V. Meiring Naudé, 25 June 1979.

Paratypes: NHMUK - 1983.11.5.56., SM239 - Eastern Cape, South Africa $\left(32^{\circ} 14.8^{\prime} \mathrm{S} 29^{\circ} 00.8^{\prime} \mathrm{E}\right)$, depth $90 \mathrm{~m}$, collected by the R.V.Meiring Naudé, 25 June 1979; NHMUK - 1983.11.5.66., SM164 - Eastern Cape, South Africa $\left(33^{\circ} 04.6^{\prime} \mathrm{S} 28^{\circ} 06,6^{\prime} \mathrm{E}\right)$, depth $90 \mathrm{~m}$, collected by the R.V. Meiring Naudé, 26 May 1978.

\section{Description}

Colony encrusting, forming small, unilaminar, irregular patches. Autozooids broad and flat, rounded distally, weakly elongate-rectangular, occasionally wider mid-length or proximally [ZL 720-880 (794), ZW 440-640 (514)]; interzooidal boundaries indicated by a smooth, narrow, non-porous strip around the zooids. Frontal shield weakly convex, granular, with numerous relatively close spaced pseudopores; areolar-septular pores mostly absent, occasionally 1-2 per zooid along lateral margin. Orifice with distinct transversely D-shaped anter that is wider than long [OL 160-200 (178), OW 120-160 (140)]; sinus longer than wide with distal corners curving inwards and proximal end rounded; proximal margin of anter, upon which denticled condyles are set, slopes upwards towards the sinus opening, with lateral corners deeply notched; four equally sized large spine bases present with one shorter pair of spines positioned distally and larger pair positioned mediolaterally on either side of orifice. Small, paired, lateral-oral avicularia present at level of sinus; slightly oval-shaped with complete crossbar. One ovicell present; at the growing edge; ooecium appearing as a low bulge, the exterior skeletal surface cryptocystal, granular, imperforate; orifice distorted. Mural communication pores set low in lateral walls inset in buttressed recesses; distal transverse wall with 1-3 large multiporous septula. Ancestrula not seen in examined material.

\section{Remarks}

Taylorius nyembezi sp. nov. was first reported from South Africa as Escharina waiparaensis (Brown, 1952) by Hayward \& Cook (1983). These authors noted that the South African specimens were interesting in that they were the only representation of $E$. waiparaensis outside of New Zealand, where this species was reported from the Miocene (Brown 1952) and Pliocene (Brown 1954), and as extant from Three Kings Islands, New Zealand, by Powell (1967). Hayward \& Cook (1983) remarked that the specimens were 'identical' to the recent specimens (BMNH 1964.8.12.59C, 59D) reported by Powell (1967), which presumably they had examined. Subsequently Gordon (2014) erected six new species (viz., Taylorius arcuatus, T. cylindratus, T. incognitus, T. masoni, T. spinosus, T. waiparaensis) for the same recent specimens of the New Zealand material and together with the fossil species erected a new genus (viz. Taylorius). Gordon (2014) noted that the South African material reported by Hayward \& Cook (1983) is potentially a new species with placement in Taylorius.

Taylorius nyembezi sp. nov. is most similar to T. waiparaensis, T. arcuatus and T. cylindratus. T. nyembezi differs from T. waiparaensis (see Figures 10H, 11A-C in Gordon 2014) in colony form, which is encrusting in the former and bilamellar-foliaceous in the latter, as well as in the metrics of zooids and orifices (see Table 1). The anter shape of T. arcuatus, T. cylindratus and T. nyembezi are all very similar, but the most obvious features distinguishing the latter is its relative long sinus (i.e. it is longer relative to total orifice length), the shape of the proximal margin of the anter (seen unequivocally with SEM) and the large size and position of the spine bases (see Figure 10F and G in Gordon 2014). These characters appear to have usefulness in species discrimination within Taylorius. No measurements were done on the ooecium and female orifice of T. nyembezi, as the colony was fragmented, and only one ovicell was observed towards the growing edge. These unique characters are considered sufficient to warrant erecting T. nyembezi as a new species. 

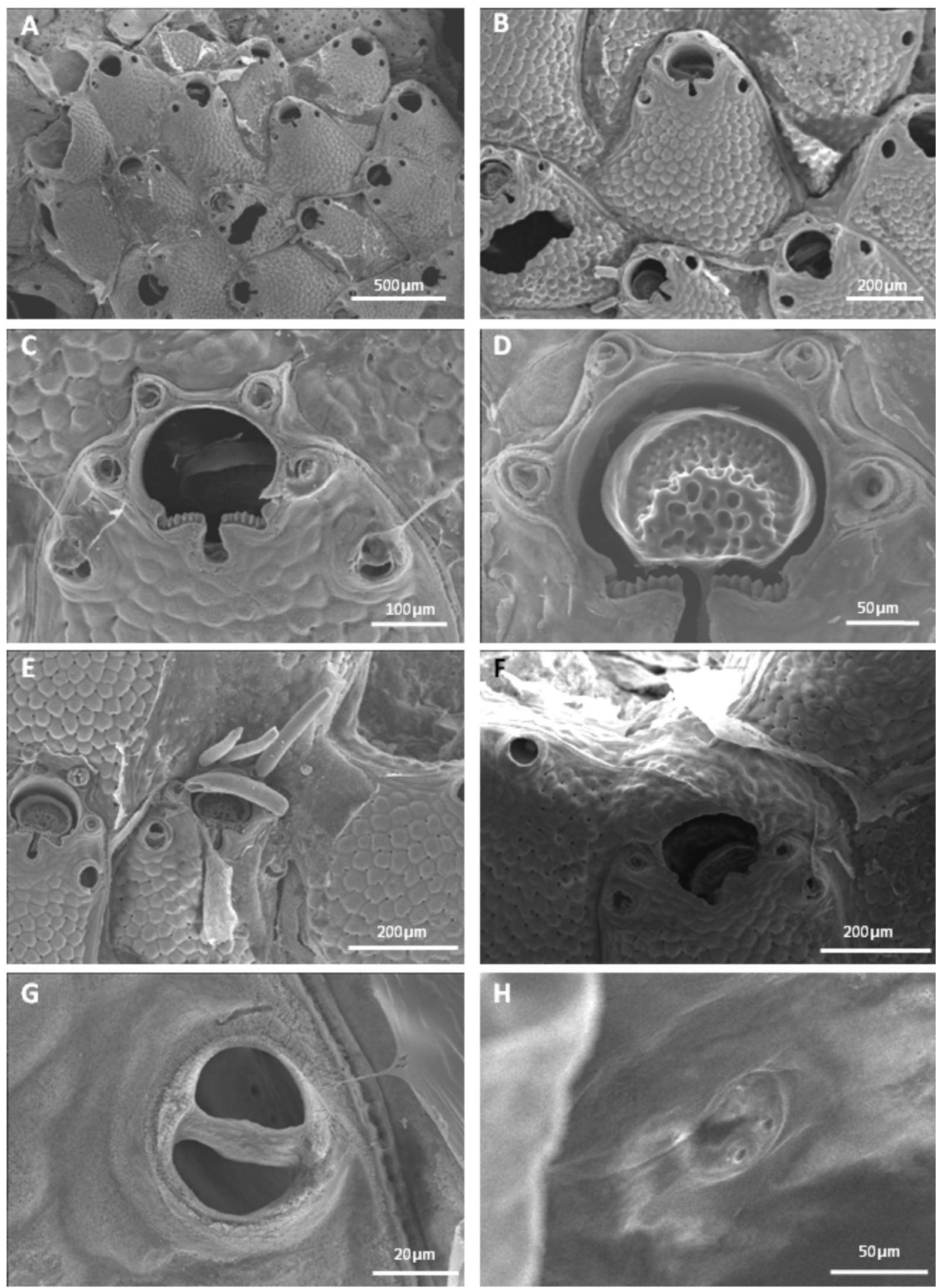

Fig. 1. Taylorius nyembezisp. nov., SAMC-A026610, holotype, from SM 239, Eastern Cape South Africa: A, part of the encrusting colony showing arrangement of autozooids; B, Autozooid; C, autozooid orifice with associated spine bases, setiform avicularia, sinus and condyles; D, operculum with pitted frontal surface; $\mathbf{E}$, arrangement of oral spines; $\mathbf{F}$, ooecium and maternal orifice; $\mathbf{G}$, oval avicularium with complete crossbar; H, multiporous mural septulum. 
Table 1. Summary of differences between the New Zealand and South African species of Taylorius (measurements in micrometres, means in brackets). Amended from Gordon (2014).

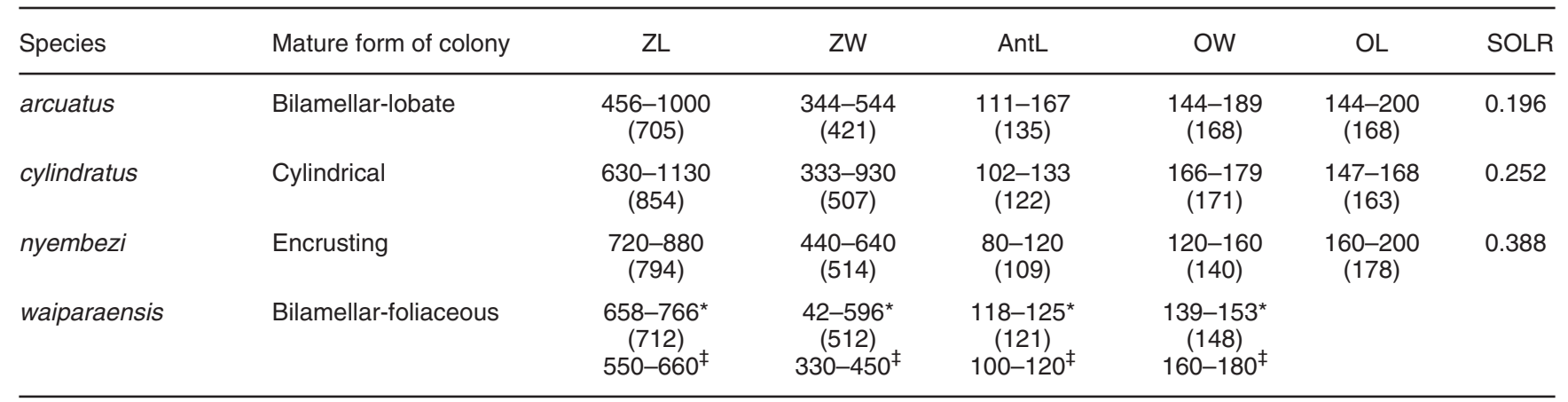

†Fossil species; *measured from SEMs of Brown's (1952) holotype; Powell's (1967) measurements.

\section{ACKNOWLEDGEMENTS}

The authors are thankful to Albé Bosman for his valuable input and comments on previous versions of the paper and for assistance with SEM images. Candice Untiedt is thanked for comments on the manuscript. Elizabeth Hoenson and Mary Spencer Jones are thanked for access to specimens lodged at the Natural History Collections Department, Iziko Museums of South Africa, Cape Town, and the Natural History Museum, London, respectively. Lastly the authors are thankful to Dennis Gordon for his guidance and for providing a much respected opinion on the diagnosis.

\section{REFERENCES}

ALLMAN, G.J. 1856. A Monograph of the Freshwater Polyzoa, including all the Known Species, both British and Foreign. 119 pp. London: The Ray Society.

BERNING, B., TILBROOK, K.J. \& ROSSO, A. 2008. Revision of the north-eastern Atlantic and Mediterranean species of the genera Herentia and Therenia (Bryozoa: Cheilostomata). Journal of Natural History 42: 1509-1547.

BROWN, D.A. 1952. The Tertiary Cheilostomatous Polyzoa of New Zealand. 405 pp. London: Trustees of the British Museum.

BROWN, D.A. 1954. Polyzoa from a submerged limestone off the Three Kings Islands, New Zealand. Annals and Magazine of Natural History 7: 415-437.

BUGE, E. 1957. Les Bryozoaires du Néogène de l'ouest de la France et leur signification stratigraphique et paléobiologique. Mémoires du Muséum National d'Histoire Naturelle 6: 1-436.

BUSK, G. 1852. An account of the Polyzoa, and sertularian zoophytes, collected in the voyage of the Rattlesnake, on the coasts of Australia and the Louisiade Archipelago, \&c. In: MACGILLIVRAY J. (ed.), Narrative of the Voyage of H.M.S. Rattlesnake, Commanded by the Late Captain Owen Stanley,
R.N., F.R.S. ETC. During the Years 1846-1850; Including Discoveries and SURVEYS in New Guinea, the Louisiade Archipelago, etc., to which is Added the Account of Mr. E. B. Kennedy's Expedition for the Exploration of the Cape York Peninsula. 1 343-402. London: T.W. Boone.

d'HONDT, J.L. 1985. Contribution à la systématique des Bryozoaires Eurystomes. Apports récents et nouvelles propositions. Annales des sciences naturelles, Zoologie et biologie animale 7: 1-12.

DAVID, L. \& POUYET, S. 1978. Le genre Herentia Gray 1848 (Bryozoa, Cheilostomata). Systématique et phylogenèse, biostratigraphie et biogeography. Documents des Laboratoires de Géologie de la Faculté des Sciences de Lyon 4: 167-193.

GORDON, D.P. 2014. Apprehending novel biodiversity - fifteen new genera of Zealandian Bryozoa. Journal of the Marine Biological Association of the United Kingdom 94: 1597-1628.

GRAY, J.E. 1848. List of the Specimens of British Animals in the Collection of the British Museum. 1. Centroniae or Radiated Animals. 173 pp. London: British Museum.

HAYWARD, P.J. \& COOK, P.L. 1983. The South African Museum's Meiring Naudé Cruises. Part 13, Bryozoa II. Annals of the South African Museum 91: 1-161.

HAYWARD, P.J. 1979. Systematic notes on some British Ascophora (Bryozoa: Cheilostomata). Zoological Journal of the Linnean Society 66: 73-90.

JULLIEN, J. 1882. Dragages du 'Travailleur', Bryozoaires. Espèces draguées dans l'Océan Atlantique en 1881. 6: 37 pp. Bulletin de la Société Zoologique de France.

MILNE EDWARDS, H. 1836. Histoire des Polypes. In: LAMARCK J.B.P.A. de. Histoire naturelle des animaux sans vertèbres. Paris: J.B. Baillière 2: 1-684.

POWELL, N.A. 1967. Polyzoa (Bryozoa); Ascophora, from North New Zealand. 34: 195 pp. Discovery Reports.

TILBROOK, K.J. 2006. Cheilostomatous Bryozoa from the Solomon Islands. 385 pp. Santa Barbara Museum of Natural History. 